Article

\title{
Current Practice of Managing the Waste of the Waste: Policy, Market, and Organisational Factors Influencing Shredder Fines Management in Sweden
}

\author{
Tharaka Gunaratne ${ }^{1, * \mathbb{C}}$, Joakim Krook ${ }^{1}$ and Hans Andersson ${ }^{2}$ \\ 1 Division of Environmental Technology and Management, Linköping University, 58183 Linköping, Sweden; \\ joakim.krook@liu.se \\ 2 Business Administration Division, Linköping University, 58183 Linköping, Sweden; hans.andersson@liu.se \\ * Correspondence: tharaka.gunaratne@liu.se; Tel.: +46-13-281-829
}

Received: 23 October 2020; Accepted: 13 November 2020; Published: 16 November 2020

check for updates

\begin{abstract}
The recycling-industry residue called shredder fines (fines) presents a disposal problem, incurs handling costs, and reduces resource efficiency in general. This study aims to identify the challenges of facilitating fines valorisation in the Swedish context. Hence, the shredding company perspective of the underlying factors that sustain the current practice of fines management is established by studying the case of a specific shredding company using semi-structured interviews. Utilisation in landfill covering offers the company a secure outlet and a legislatively-compliant low-cost disposal option for fines. Additionally, lack of specific regulatory standards, unfavourable regulation of waste reutilisation, and lack of market demand for secondary raw materials (SRMs) create disincentives to develop valorisation options. Also, the lack of corporate-level focus on the issue has resulted in a lack of organising for and capacities to improve the handling of the material. Initiating fines valorisation needs to challenge these prevailing circumstances and thus necessitates governmental interventions. Simultaneously, favourable conditions for SRM utilisation are needed; that is, established outlets for fines-derived SRMs and clear regulatory and market playing rules that reduce uncertainty and investment risk of developing tailored processes for upgrading and resource recovery need to be available.
\end{abstract}

Keywords: current practice; fines valorisation; policy; market; organisation

\section{Introduction}

Recycling-based economic development has been a priority for the European Union (EU) for the last couple of decades [1]. Consequently, the need for increased resource efficiency has been recognised and closing material loops envisaged [2]. In this context, the recycling industry's role becomes increasingly important not only as a caretaker of waste but also as a producer of raw materials to other societal sectors. At the end of product life, however, current collection and recycling processes are capable of retaining the value of only a fraction of the materials, while considerable amounts are either down-cycled to low-quality resources or disposed of [3]. In addition, many recycling processes focus on only one or a few targeted outputs and thus end up generating large quantities of heterogeneous residues that end up as wastes. Such residues, generated by the waste management industry from the processing and resource recovery of waste and herein called the waste of the waste, are often technically challenging and economically unappealing to valorise [4], and hence disposed of in landfills in many parts of the world. This practice causes a continuous loss of resources and adds waste disposal costs to the recycling industry.

The shredding industry is primarily based on recycling metals from discarded products and materials. In this industry, end-of-life vehicles (after dismantling and depollution), municipal white 
goods, and industrial scrap are typically shredded [5,6] for the subsequent retrieval of ferrous and non-ferrous (copper and aluminium) metals. What remains after this metals recovery is a heterogeneous material known as shredder residue, which usually is landfilled in many parts of the European region $[5,7,8]$. In certain countries (e.g., Sweden and Belgium), however, advanced processes are employed to further retrieve metals and other resources such as plastics and rubber from the larger fractions of shredder residues. Nevertheless, the fine-granular fraction of the shredder residue, also called "shredder fines" or merely "fines", often recognised as the fraction of shredder residues that is less than $20 \mathrm{~mm}$ [9], is virtually always disposed of in the region [10].

In Sweden, shredder fines is primarily utilised as a bulk material in landfill covering. At the beginning of this century, stringent landfill emission standards were introduced in the Swedish landfill ordinance [11] in conjunction with the EU landfill directive's [12] focus on the environmental impacts of landfills. This required substantial investments in landfill infrastructure and treatment technology, leading to a rapid closure of many landfills in the country $[13,14]$ that could not afford such investments. Consequently, a large demand for landfill cover materials (LCMs) came into existence, creating an outlet for many industrial residues, including fines. However, the future of this disposal-oriented practice of managing fines is not certain. Given that most landfills are now closed, the present demand for LCMs is decreasing fast. What is more, the country has been phasing out landfilling as a waste management practice [14], and thus, the demand for LCMs will eventually disappear. Less demand for LCMs also means more competition between different residues for such available disposal outlets, which would likely lead to higher gate fees for such materials. This situation indicates that the current landfill-related disposal of fines will become increasingly expensive in the future and is not a long-term solution. Hence, in order to avoid increased costs and future disposal problems, a need for alternatives for fines management based on valorisation (i.e., material upgrading and resource recovery), is foreseeable for the country's shredding industry.

Previous research concerning fines is primarily technically focused, consisting of studies that have investigated material characteristics and processes development. Material characterisation studies have assessed potential resources such as metals, plastics, and minerals, and contaminants such as heavy metals and organic pollutants [15-18]. The process development studies have investigated either the retrieval of specific resources contained in the material $[19,20]$ or the reutilisation of fines as a substitute bulk material [21,22], for instance, in ground construction applications such as road base layer, noise barriers, parking lots, and play areas. While these two types of studies provide valuable contributions regarding assessing the resource potential of fines and developing upgrading (i.e., addressing material constraints) and resource recovery processes, they also carry substantial knowledge limitations [9]. The material characterisation studies have only assessed a few out of many materials, thus limiting the knowledge on potentially recoverable resources and possible material constraints. Furthermore, such studies have only analysed one or a few size fractions obtained from one or a few randomly collected samples, which hinders the development of valorisation processes. The process development studies generally overlook the full recovery of fines (i.e., both the retrieval of specific resources to retain value and bulk utilisation to avoid disposal). Furthermore, such processes are in a very early phase of development, and they have mostly been performed on a lab-scale and only investigated one or a few process attributes, thus limiting their applicability in actual process development. Hence, the realisation of fines valorisation seems to rely on significant investments in knowledge and technology development and upscaling.

The current practice of utilising residues such as fines in landfill covering in Sweden has evolved over several decades and is anchored in the societal context of the country (cf. [23]). In order to realise fines valorisation, a change to this prevailing practice needs to be initiated. Such change necessitates knowledge of the circumstances and settings that sustain it [24,25] on different societal levels. For instance, waste policy, via administrative and market instruments [26,27], would provide the overall governance to the potential valorisation-based recovery applications (valorisation applications), while local authorities would provide regulation [28]. The market for secondary raw materials 
(SRMs) would determine outlets and prices for potential fines-derived SRMs, and thus, the economic feasibility of fines valorisation [29]. Additionally, the producer's capacities to influence material flows [30] and how they are internally organised would determine the actual practice of managing fines. Systemic knowledge of how such factors and their interrelations influence the current practice of fines management is lacking [9].

The overall aim of this study is to provide systemic knowledge that could facilitate changed practices and initiate investments in knowledge and technology development for fines valorisation in the Swedish context. In order to develop such knowledge, the underlying policy, market, and organisational factors of the current practice of shredder fines management in Sweden are established. Based on that, the two-fold challenges of realising changed practices, that is, challenging the prevailing disposal-oriented practice and creating better conditions for SRM utilisation, are identified, and potential measures to address them are discussed.

\section{Materials and Methods}

A qualitative empirical approach was employed in this study. Given the study's objective, obtaining qualitative data was deemed more suitable compared to quantitative data, as it can refer to meanings, descriptions, and characteristics [31,32] of various aspects related to and which could potentially influence fines management. Data that could capture the influence of policy, market, and organisational aspects on fines management were collected, primarily using interviews with industry practitioners. Face-to-face interviews were deemed most appropriate to capture the idiosyncrasies and complex perceptions associated with the issue at question [31], and expressions and body language necessary to interpret the data accurately. A thematic analysis of the collected data was performed in accordance with the process of data reduction, data display, and drawing conclusions [31]. A thematic analysis facilitates the aggregation of qualitative data scattered throughout the interviews. Thereby, factors underlying the current practice of fines management were established. Based on these findings, the challenges and potential measures of facilitating changed practices and initiating investments in knowledge and technology development for fines valorisation were discussed.

The shredding company perspective was the focus of the study because they (shredding companies) own the material and the responsibility of managing it. The current practice of utilising fines in landfill covering is a well-established practice that has provided a secure outlet for fines, and hence, any valorisation-based alternative would presumably have to be initiated by this actor. Additionally, such an actor perspective is necessary to establish how possible governmental policy interventions would be perceived by them, influence their motives for managing fines, and could actually facilitate fines valorisation. The case of a particular shredding company and its management of fines was studied due to several reasons. It enables the development of concrete and in-depth knowledge of the issue [32] and obtaining rich empirical data via close interactions with personnel. Additionally, it facilitates study visits so that authors could gain on-site experience on the actual handling of the material.

\subsection{The Case and Study Object}

A major shredding company, out of the three shredding companies currently operational in Sweden, was selected for the study. It is a large-scale company that is operational in multiple sites across southern Sweden, accounts for around a 60 percent share of the country's shredding industry, and shreds approximately one million tons of materials and generates approximately 100,000 tons of fines annually. Other than post-shredder resource recovery, the company is also involved in recycling electric and electronic waste. The company is operational in many parts of the country and owns multiple shredding plants and landfills. It also supplies SRMs to several users, primarily, metals to smelters and plastics as alternative fuels to cement plants. The particular company was selected for two main reasons. One is that the large-scale operations and the involvement with various local authorities and in SRM markets would cover the potential variance in policy and market factors related to managing fines in the country. The other reason is that the company, having been involved in 
shredding operations for four decades, was presumed to have a vast knowledge of the material and experience in its handling.

The object of the study was the fines management by the involved shredding company (Figure 1). The company's current practice of fines management was recognised as a consequence of both incentives for utilising the material in landfill covering and disincentives for developing valorisation options. Such motives (incentives and disincentives) were understood to be created by both external factors, that is, policy and SRM-market factors, which are beyond the company's control, and company-internal factors, that is, LCM-market and organisational factors, which are within the company's control. Policy factors were considered to stem from aspects such as administrative and market instruments and regulation by local authorities concerning waste management in general and fines management in particular. SRM markets operate as traditional markets where several suppliers and users participate in trade. Thus, the related factors of potential influence were considered to stem from aspects such as supply, demand, and competition. Landfills, the current outlets for fines, are identified as markets as there is a demand for LCMs, and they operate based on agreements between suppliers and users. Primarily, the company's own landfills are involved, but occasionally, third-party landfills are used; nevertheless, the company has good relations with such landfills, and operationally, it has control over utilising fines in those landfills. Therefore, LCM markets were considered to be internal and on the border of the shredding company's boundary. The related factors of potential influence were considered to stem from aspects such as remaining landfill volumes and goodwill between parties. Organisational factors were considered to stem from internal organisational aspects occurring at two levels of the company. At the corporate level, strategic approaches, that is, approaches based on long-term objectives [33], are developed concerning various business activities like fines management via priority setting, investment decision making, and resource allocation. At the fines management level, the strategic approach for fines management is operationalised, influenced by capacities (know-how and resources) to do so and organising for it.

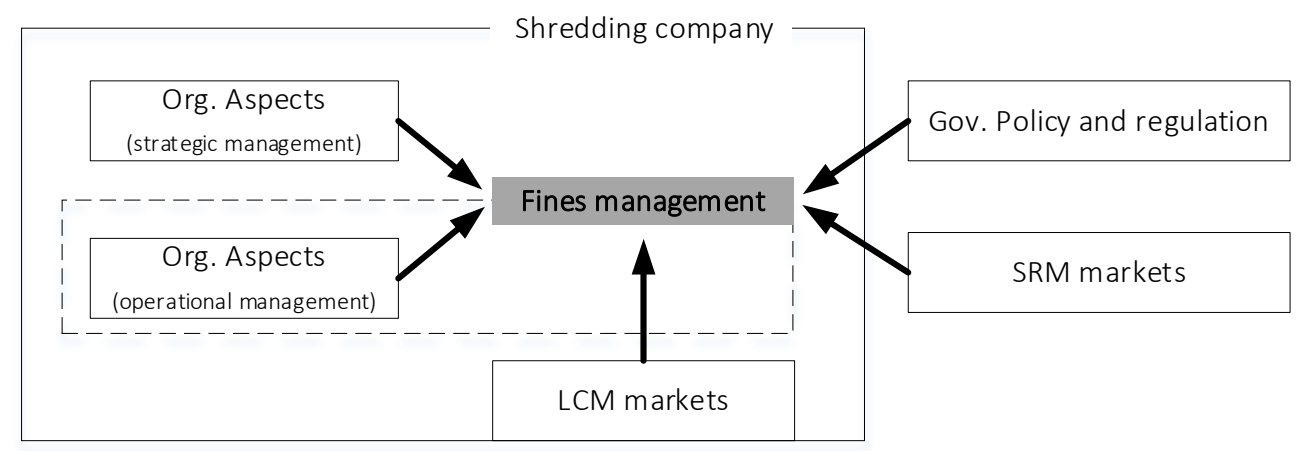

Figure 1. Schematic illustration of the external and internal factors influencing the shredding company's fines management motives.

\subsection{Data Collection}

The empirical data collection was primarily done via semi-structured, face-to-face interviews with seven selected employees representing different functional areas of the involved company (interview guides are provided as Supplementary Materials). The interviews were audio-recorded and lasted from 45 to $75 \mathrm{~min}$. Follow-up questions were asked over the phone and email in order to get more information and further clarification. Functional areas relevant for the study, and the corresponding interview respondents (Table 1), were selected together with a panel of experts from the company to ensure all the company's operations related to the generation and management of fines were encompassed. Corporate management involves overall decision making regarding business strategies, new investment, and operational directions. Processing is the company's core business activity where shredding and post-shredder resource recovery take place and fines is generated. Regulatory affairs is involved in working with waste policy, legislation, and local authorities that 
together provide overall governance to handling fines. Environmental permits works with local authorities regarding environmental assessments for the authorisation of handling fines. Sales is involved in finding markets for SRMs, which is a key issue in the case of potential valorisation of fines. Some of the selected respondents have divided responsibilities in more than one functional area (e.g., Interviewees 2 and 7), whereas all respondents were involved in company-level operations beyond fines management.

Table 1. The scope of the interviews. The selected functional areas for the interviews, work tasks of the respondents, and the general and specific focuses of the interviews are presented.

\begin{tabular}{|c|c|c|c|c|}
\hline Functional Area & $\begin{array}{l}\text { Interviewee } \\
\text { No. }\end{array}$ & Work Task & $\begin{array}{l}\text { General Focus in All } \\
\text { Interviews }\end{array}$ & Specific Focus in Functional Areas \\
\hline \multirow{2}{*}{$\begin{array}{l}\text { Corporate } \\
\text { management }\end{array}$} & No. 2 & $\begin{array}{c}\text { Manager: } \\
\text { Recycling facility }\end{array}$ & \multirow{8}{*}{$\begin{array}{l}\text { - } \begin{array}{l}\text { Significance of } \\
\text { managing fines to } \\
\text { the company }\end{array} \\
\text { Drivers and } \\
\text { barriers of current } \\
\text { handling of fines } \\
\text { - } \begin{array}{l}\text { Necessary } \\
\text { conditions for } \\
\text { fines valorisation }\end{array} \\
\text { - Organising for } \\
\text { handling fines }\end{array}$} & \multirow{2}{*}{$\begin{array}{ll}\text { - } & \text { Internal aspects } \\
\text { - } & \text { Strategic approach for } \\
\text { managing fines } \\
\text { - } & \text { Investment decision making } \\
\text { - } & \text { Demand for LCM } \\
\end{array}$} \\
\hline & No. 7 & $\begin{array}{c}\text { Manager: } \\
\text { Alternative raw } \\
\text { materials division }\end{array}$ & & \\
\hline \multirow{3}{*}{ Processing } & No. 1 & $\begin{array}{l}\text { Process manager: } \\
\text { Post-shredder } \\
\text { resource recovery }\end{array}$ & & \multirow{3}{*}{$\begin{array}{ll}\text { - } & \text { Internal aspects } \\
\text { - } & \text { Responsibility for } \\
\text { - } & \text { Technanical know-how } \\
& \text { concerning fines } \\
\text { - } & \text { Resources for managing fines }\end{array}$} \\
\hline & No. 2 & $\begin{array}{l}\text { Process manager: } \\
\text { Post-shredder } \\
\text { resource recovery }\end{array}$ & & \\
\hline & No. 3 & $\begin{array}{l}\text { Process manager: } \\
\text { Shredding }\end{array}$ & & \\
\hline Regulatory affairs & No. 6 & $\begin{array}{l}\text { Legal } \\
\text { representative }\end{array}$ & & $\begin{array}{ll}\text { - } & \text { External aspects } \\
\text { - } & \text { Waste policy and legislation } \\
\text { localatory practices of } \\
\\
\text { lochorities }\end{array}$ \\
\hline $\begin{array}{l}\text { Environmental } \\
\text { permits }\end{array}$ & $\begin{array}{l}\text { No. } 4 \\
\text { No. } 5\end{array}$ & $\begin{array}{l}\text { Responsible for } \\
\text { environmental } \\
\text { permits }\end{array}$ & & $\begin{array}{ll}\text { - } & \text { External aspects } \\
\text { - } & \text { Env. Assessment of } \\
\text { landfill disposal } \\
\text { - } \quad \text { Env. Assessment of } \\
\text { waste valorisation }\end{array}$ \\
\hline Sales & No. 7 & $\begin{array}{c}\text { Manager: } \\
\text { Alternative raw } \\
\text { materials division }\end{array}$ & & $\begin{array}{ll}\text { - } & \text { External aspects } \\
\text { - } & \text { Demand for SRMs } \\
\text { - } & \text { User requirements on SRMs } \\
& \text { fines-derility of } \\
& \text { ined SRMs }\end{array}$ \\
\hline
\end{tabular}

Subsequently, two-fold interview guides (provided as supporting information) were developed. That is, the general structure of the interview guides carried questions directed to all interviewees, and within that, specific questions were added for each functional area. The general structure was developed to capture the current practice of fines management in relation to the key issues of general relevance. The strategic significance (refers to having a secure outlet and economic and market performance) of managing fines was addressed as it would constitute the company's primary motives [29] in managing the residue. The policy and market drivers and barriers were addressed since they could be considered the key factors that would influence the strategic significance of managing the residue [28]. Similarly, the perceived policy and market circumstances and settings that need to be in place to facilitate fines valorisation were addressed in order to establish the current disincentives for doing so. The level of internally organising for handling fines plays an essential and necessary part in the operational management of the residue, especially when it comes to the potential valorisation that would involve implementing change, and hence was addressed in relation to the level of communication and cooperation [34] between the functional areas. 
Within this general structure, emphasis was also given to specific aspects pertaining to the functional areas in order to obtain detailed insights on such aspects. In doing so, the functional areas were also perceived in relation to the internal and external aspects. Regarding internal aspects, corporate management was addressed to capture the organisational aspects occurring at the corporate level, such as the strategic approach [35] for managing fines (strategic management) and LCM-market aspects such as the existing demand for such materials [13]. Processing was primarily addressed to capture the organisational aspects in relation to handling the material (operational management) occurring at the fines management level because the current handling of fines primarily takes place via this functional area. An example of such organisational aspects is the responsibility of managing fines, which was addressed to establish the extent to which fines management has been incorporated into the organisational structure. Regarding external aspects, both regulatory affairs and environmental permits were addressed to capture the policy and regulation aspects concerning current disposal as well as possible future valorisation of the residue [28]. An example of such policyand regulation-related aspects is the availability of clear regulatory standards for SRM reutilisation applications. Sales was addressed to capture the SRM-market aspects such as user demand and material quality requirements [36].

\subsection{Data Analysis}

The analysis of the empirical data consisted of an interactive process of data reduction (tagging), data display (theme development), and drawing conclusions (data interpretation) [31], as illustrated in Figure 2. First, the interview recordings were transcribed in order to facilitate the analysis of the empirical data. Then, the transcriptions were processed with tags that were generated along the way in order to highlight different aspects that were addressed in the interviews. Subsequently, themes that represent implicit topics characterised by a group of tags [37] were formulated to identify potential factors influencing fines management (a detailed overview of the themes are provided as Supplementary Materials). The influences of these identified factors on the fines management by the studied company were interpreted based on what was mentioned in the interviews as well as other sources of data and information. Finally, based on the above analysis, the challenges of initiating fines valorisation and measures to address them were discussed.

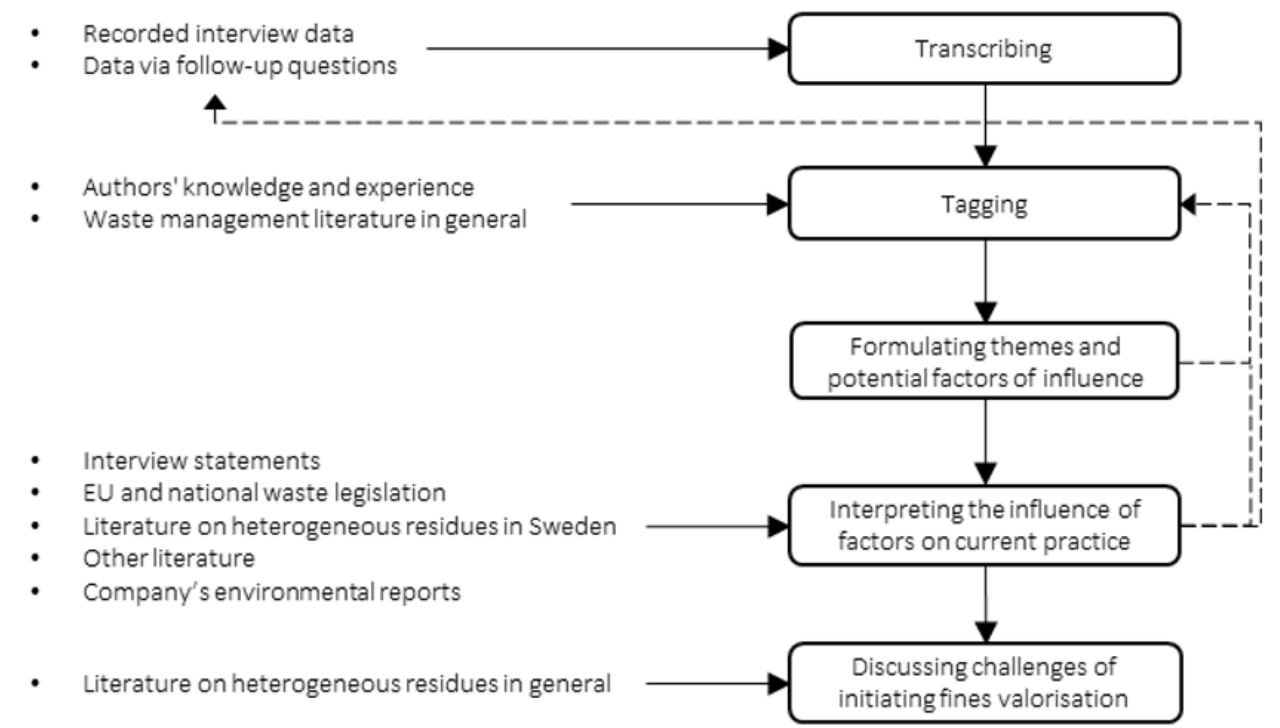

Figure 2. Employed analytical approach of the study. The interview-based qualitative data were processed with tags and themes in order to facilitate the interpretation of factors influencing the current practice of fines management by the studied shredding company. 
Tagging the transcribed data involved producing a gross list of external and internal aspects raised by the interview respondents, potentially significant to fines management. This was performed by referring to specific statements and information from the interview respondents [32]. Certain statements and information were obvious on a particular aspect of significance. An example is, "there is no dedicated team for fines management". This directly refers to and is thus tagged as organisational structure. Certain statements were not as obvious, and hence, had to be tagged based on the authors' knowledge and experience on and by consulting literature related to the subject. An example is, "the biggest problem is that they are still much focused on seeing waste as an environmental burden". This was understood as referring to governmental institutions (waste legislation and regulatory authorities) focusing more on the environmental and health risks rather than the resource potential of waste. Thus, it was tagged as institutional perceptions. Such tags were cross-checked with the respective respondent to ensure accuracy. Certain statements referred to more than one aspect and thus led to multiple tags. An example is, "our landfills are filling up very fast; once landfills are no longer the solution, we need to have an option". This statement refers to and is tagged as both reducing landfill space and the preference to dispose of.

Groups of tags characterised particular themes related to fines management. Certain tags characterised more than one theme. As new themes were emerging, the tagging step was revisited to find new tags that characterise such themes. Hence, tagging and theme development were performed iteratively until saturation was reached. The themes primarily referred to factors that could potentially influence the shredding company's motives on managing fines (i.e., incentives for utilisation in landfill covering and disincentives for valorisation), and hence, the current practice. Some themes referred to the future; these were, for example, likely policy developments concerning waste management, desirable market developments concerning SRMs, and the company's anticipated approach for addressing fines. A detailed illustration of the developed themes and examples of the corresponding tags are provided in supporting information.

The identified factors that could potentially influence the current practice of fines management were categorised based on whether they occur externally or internally. Subsequently, their influence in creating motives for the shredding company on managing fines was interpreted. The influence of certain factors was straightforward, as the interview data were self-revealing. In contrast, the influence of certain other factors was rather obscured in the interview data. An example of the latter is the factor environmental prudence of governmental institutions in waste regulation. The statement, "the biggest problem is that they are still much focused on seeing waste as an environmental burden", implies that it creates a disincentive for fines valorisation, but does not reveal how exactly. In such instances, secondary data sources were referred to. Generally, the interpretation of external (policy and SRM-market) factors was facilitated by referring to EU and national waste policy and legislation, and previous literature on heterogonous residues in Sweden. Interpretations of the influence of internal organisational factors were facilitated by referring to literature concerning organisational theory. Secondary data were also used to add perspectives to the interpretations. For instance, the company's environmental reports were referred to regarding the quantities of fines generated and utilised as LCM. As much as the individual factors, the significance of interrelations between them in creating motives for the company was recognised. Thus, the interrelations within the external and internal factors, as well as between them, were addressed. In certain instances, the interpretations called for more data, which were obtained via follow-up questions. As the interpretations were being made, the tags were revisited to ensure all data that confirmed or contradicted such conclusions were accounted for. In this interpretation, special emphasis was put on the over-time change [38] of the company's approach to managing fines.

Finally, based on the analysis, the challenges of facilitating fines valorisation were synthesised, and measures to address them discussed. This concluding discussion was performed in relation to initiating changed practices by removing the incentives for fines disposal and supporting shredding companies to opt for fines valorisation by addressing current disincentives. The discussion was 
primarily performed by relating to the literature on fines and other heterogeneous residues, such as municipal bottom ash, shredder residues, construction and demolition waste, and previously landfilled waste. It was further facilitated by referring to the shredding company perspective on the necessary policy- and market-related circumstances and settings for fines valorisation. Thus, recurring issues related to the valorisation of heterogeneous residues in general, as well as specific issues related to the potential valorisation of fines in Sweden, were highlighted.

\section{Results}

Historically, shredder residues (including fines) were landfilled by the studied company (Interviewees 1 and 2). Two decades ago, the EU landfill directive [12] came into force, and one of its primary objectives was to discourage the landfilling of potentially recoverable materials. This caused the introduction of landfill taxes [39] and a landfill ban on organic-rich (more than 10\%) materials [11] in Sweden. These policy instruments drove the company to process shredder residues to recover resources and minimise disposed quantities (Interviewee 2). Continuous improvements in processing technology have enabled the processing of smaller fractions, thus reducing the size of fines from 20 to $10 \mathrm{~mm}$ (Interviewees 1 and 2) over time. Yet, the amounts of fines generated have not decreased accordingly, given the constant increase in material input to the shredder owing to the increased production and consumption of goods. The strict landfill-related regulations and the subsequent large-scale closure of such sites created a market for LCMs, which since then has been the main outlet for shredder fines. As far as the fines management by the studied company is concerned, the analysis of the empirical data reveals various external and internal factors of influence related to policy, market, and organisational aspects (Figure 3). Here, the implications of such factors and their interrelations for the current management of fines are presented in terms of how they create incentives for continued utilisation as landfill cover material and disincentives for the development of valorisation options.

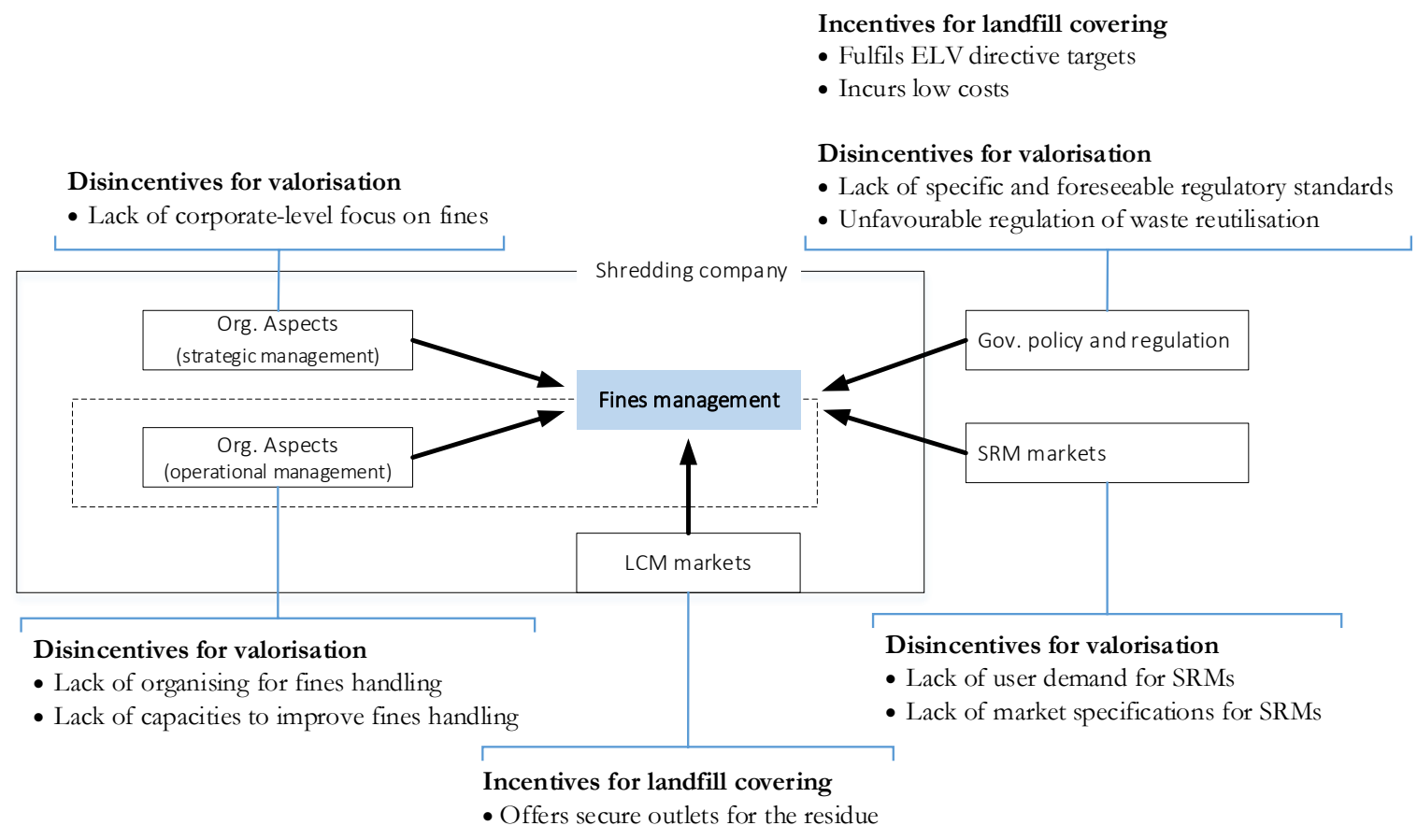

Figure 3. Illustration of the externally- and internally-created motives due to policy, market, and organisational factors on the current practice of fines management at the studied shredding company. 


\subsection{Incentives for Continued Utilisation in Landfill Covering}

\subsubsection{Externally-Created Incentives}

One of the primary externally-created incentives for the company to continue utilising fines in landfill covering is that it contributes to fulfilling the end-of-life vehicles directive (ELV directive) targets. The company has contractual obligations towards vehicle manufacturers to comply with the directive targets (Interviewee 6). The directive requires 95\% recovery and 85\% recycling of the bodyweight of discarded vehicles [40], which only allows for 5\% disposal. Today, fines generated at the company represents around a 10\% share of the feed material that consists of a blend of ELVs, white goods, and industrial scrap (data from environmental reports 2014-2017). Even though a dedicated trial has proven that the share of fines is less than that when only ELVs are shredded (Interviewee 2), compliance with directive targets is more or less still dependent on fines' recovery. Landfill covering is currently recognised as backfilling [41], which is classified as a recovery operation in the waste framework directive [42]. Due to such legislative provisions, despite the fact that the ELV directive formally recognises only thermal recovery other than recycling [43], the company has so far managed to get by with utilising fines in landfill covering (Interviewee 6).

The other primary externally-created incentive for utilising fines in landfill covering is that the recovery classification makes such use exempt from the landfill tax in Sweden [44], thus making the operational costs of fines management significantly low. For instance, the current costs of this practice range from 100-300 SEK/ton, where the actual cost is determined by tipping fees (in the case of third-party landfills) and transportation (Interviewee 5). The costs would be significantly higher if fines were to be landfilled, which is the currently available alternative, given the tax of 500 SEK/ton [39]. Due to the relatively high organic content in fines, such disposal would also require an exemption from the local authorities given the existing landfill ban on organic-rich residues, a time-consuming and arduous administrative process for the company.

\subsubsection{Internally-Created Incentives}

A prominent factor that internally creates a strong incentive for the company to utilise fines in landfill covering is that such use offers a secure outlet for fines. Primarily, the company's own landfills are used for this purpose, although third-party landfills with which the company has close relationships are occasionally used (Interviewee 1). There is still a significant demand for LCMs in these landfills, and such utilisation thus offers long-term outlets for fines as it is a continuous process that takes place over several years. Decades of operations have allowed these utilisation routes to gradually evolve and establish administratively and logistically. Landfill covering also provides a means for disposal of fines, which the company perceives as a problematic material. One of the main reasons for this perception is that the focus has so far been on the occurrence of contaminants (especially heavy metals) in fines, which is required by local authorities in authorising its disposal. The other main reason is the company's limited knowledge of the resource potential of the material. Detailed knowledge of the material is, in fact seen as something that might even draw unnecessary attention that could jeopardise the current means of managing this problematic material. This was once expressed as, "sometimes I feel that we don't really want to know" (Interviewee 6).

\subsection{Disincentives for Developing Valorisation Options}

\subsubsection{Externally-Created Disincentives}

One of the primary externally-created disincentives for the company to develop valorisation options for fines is the lack of clear and foreseeable regulatory standards for the use of SRMs. The only available standards in that regard in Sweden are the guiding values developed by the national environmental protection agency (EPA) regarding the maximum contamination levels in waste to be used in landfill covering and ground construction applications [45]. However, these centrally-developed 
general values do not sufficiently account for specific conditions of different applications due to possible differences in materials, application types, and sites. Such guiding values are then used by local authorities in regulating such applications on a case-by-case basis [45]. Yet, the local authorities often lack the competence to interpret such standards in relation to the specific conditions and perform accurate risk assessments (Interviewee 6) due to the lack of experience and qualified personnel [28]. Consequently, the company has already experienced inconsistent regulatory practices by local authorities (Interviewees 4 and 5) in relation to previous initiatives for fines reutilisation in ground construction. Such non-specific and unforeseeable regulation makes the company, as a potential investor, uncertain about the technical feasibility of valorisation applications. Regulatory uncertainty among potential SRM users is also evident elsewhere. For instance, the Swedish Transport Administration, the largest potential user of SRMs in ground construction in Sweden, has been unaware of the applicable conditions for such use [28].

Another primary externally-created disincentive for fines valorisation is the unfavourable regulation of subsequent recovery applications, which could render their realisation impossible. For instance, the EPA guiding values are primarily based on the total concentration of metals [46] despite that the actual impact is caused by their biological availability [47], which is better indicated by leaching concentrations [48]. Shredder fines (and similar industrial residues such as municipal bottom ash) often contain relatively high total concentrations of metals [10], and therefore, such regulatory requirements are difficult to fulfil for shredder companies. In contrast, given that many of the metals in such residues either exist in their pure form or are tightly bound to the surrounding materials and thereby partially immobilised [47], contamination limits based on leaching concentrations are easier to fulfil. Furthermore, the current EPA guiding values presume the use of SRMs in ground construction without any protection [49]. This, however, is unlikely the practice as they will be either bound to or contained within natural materials, and thus the contaminants are mostly immobilised, and the actual risk is less than the presumed levels. Additionally, the current environmental assessments in authorizing processes for waste reutilisation emphasise local environmental and human health risks (Interviewee 6), whereas the potential global or regional benefits of such recovery are somewhat neglected. Such risk-prudent regulation could, to a large extent, be explained by the strong emphasis put in the waste framework directive on minimising hazards of waste handling [42]. However, it generates a lack of trust among shredding companies as potential investors that fines valorisation would not stand a fair trial in authorisation processes. According to the Swedish EPA, lack of trust is a primary factor that explains the decreased use of SRMs in ground construction applications in the country [28].

As far as the potential valorisation of fines is concerned, the current Swedish SRM-market conditions make it a high investment risk for the company, another primary externally-created disincentive. Given the fairly low occurrence of potentially recoverable resources in fines $[10,50]$, the potential demand for fines-derived SRMs is deemed to be low, and the identification of potential users challenging (Interviewee 7). Generally, the country's SRM markets, except for metals, are characterised by low user willingness for such materials [28]. The low user demand (or willingness) could be partly explained by the availability of primary materials at affordable prices for which the potential users have adapted their technical processes, knowledge, and regulatory understanding. An example is the widespread use of crushed bedrock instead of SRMs in ground construction. Another plausible reason for the low user demand for SRMs compared to primary materials is the need for quality assurance for each and every occasion the SRMs are utilised. This situation, which is partly explained by the aforementioned lack of specific regulatory standards for SRM-based applications, makes it difficult for suppliers such as shredding companies to maintain timely deliveries, a criterion that is paramount for certain users such as in the construction sector. A different explanation for the low demand for SRMs would be the heterogeneity and higher contamination potential of waste-based materials compared to primaries. In that regard, the prospects of fines would be further reduced given the availability of 
more homogeneous and less-contaminated alternative SRMs such as iron sand, cement, and metal slag. This narrative was once expressed as "fines will never be a gold mine" (Interviewee 6).

The lack of demand makes determining price levels for potential fines-derived SRMs and estimating costs and revenues of fines valorisation unpredictable. Thus, despite potential market opportunities in valorising fines (Interviewee 7), the company is unable to perform accurate economic assessments to justify a business case. The lack of demand for SRMs also leads to a lack of user requirements, which, together with regulatory standards, constitute market specifications regarding material quality, which is key to develop technical processes for material upgrading and resource recovery [10]. According to all the process managers (Interviewees 1, 2, and 3), the demand side of the market has to set the conditions (i.e., demand and material specifications) so that economic and technical assessments of potential fines valorisation can be performed.

\subsubsection{Internally-Created Disincentives for Valorising Fines}

One of the primary internally-created disincentives for the company to develop fines valorisation options is the lack of focus on the material at the corporate level, a situation primarily influenced by the circumstances and settings of the external environment. The strategic management of the company is quite reactive to governmental policy and SRM-market conditions. For instance, as mentioned at the beginning of this section, the processing of shredder residues for resource recovery was initiated by conditions in waste legislation that made the disposal of the material difficult and costly, thus compelling increased resource efficiency. Investments in such resource recovery were then driven by favourable market conditions-specifically, high metal prices—where the company has invested several hundreds of millions of Swedish crowns in advanced processing plants (Interviewee 2). However, when it comes to fines, the governmental policy framework does not actively require that it should be managed otherwise. What is more, the low occurrence of potentially recoverable resources $[10,50]$ and the low market demand for SRMs make the potential valorisation of fines economically unappealing. The lack of corporate-level focus on fines is also due to existing issues with the company's mainstream processes involving the larger fractions of shredder residues that carry higher resource yields and economic prospects, strategically prioritised by the corporate management (Interviewees 1 and 2 ). The company's sensitivity to the economic prospects in making strategic decisions could be summarised as "it all depends on the money" (Interviewee 3). As a consequence of the aforementioned reasons, focus on fines is lacking at the company level, and hence, a disposal-oriented approach for managing the residue is opted for.

The lack of focus at the corporate level concerning the strategic management of fines leaves its operational management in limbo. One of the adverse repercussions of this situation is that there is a significant lack of internally organising for improved handling of fines. Currently, the responsibility of handling fines is not formally recognised in the organisation structure. Apparently, the fines is handled by a manager from the functional area processing (Interviewee 1), who works together with an employee from environmental permits. Fines, in this context, is viewed rather as a burden that needs to be gotten rid of. As one of the process managers (Interviewee 3) puts it, "fines is not my speciality nor my interest". The lack of a structured approach and clear responsibilities, in turn, has led to a substantial lack of coordination and communication between the functional areas concerning managing fines. The lack of coordination is manifested in the non-congruence among the interview respondents, where all the respondents claimed the improved management of fines is someone else's responsibility. The lack of communication is manifested as the interview respondents were either unaware or unsure of fines valorisation initiatives taken elsewhere within the company. As a consequence of the unorganised approach described above, different functional areas, namely, processing, research and development, and sales, have undertaken scattered and isolated initiatives for the same goal (of valorising fines), none of which was successful. This could be seen as a traditional problem in large hierarchical organisations [51], especially ones that have been in operation for a long period of time. Moreover, having sustained over decades, the current practice of managing fines has developed a substantial 
level of embeddedness in aspects such as routines and protocols of obtaining environmental permits, generating contractual agreements with landfill owners, and logistical arrangements. That means opting for valorisation implies adopting a great deal of change, which is also difficult given the lack of internal coordination and communication [34].

Another main consequence of the lack of corporate-level focus that internally creates disincentives for fines valorisation is the lack of capacities to improve the operational management of the material. For instance, the current utilisation in landfill covering limits the company's knowledge of the materiality of fines to a few regulated substances, which are assessed as part of authorisation by local authorities. Hence, the company's knowledge of the potentially recoverable resources and possible material constraints in fines is low. Additionally, research and development on fines has been deprived of the necessary financial and human resources, which have been channelled into the prioritised mainstream resource recovery processes (Interviewee 1). Consequently, technical processes for upgrading and resource recovery are under-developed. According to all the interviewed process managers (Interviewees 1, 2, and 3), more knowledge on the material and technology development is required to be able to valorise fines. Currently, the company's limited knowledge is also manifested in the viewing of the material as a problem rather than a potential resource.

\section{Discussion}

Despite the current external and internal factors that collectively sustain the current management of fines, the company, according to all of the interviewees, anticipates policy developments targeting increased residue valorisation and the eventual disappearance of LCM markets, thus taking away the current main disposal route for the material. Hence, it is recognised by the company that landfill-related disposal is an unlikely option for fines in the future, and its general take on the long-term management of fines can be summarised as "there is no future with landfills" (Interviewee 7). Given the regional and national policy developments towards increased resource efficiency in general, the company also foresees eventual improvements in SRM-market conditions in Sweden (Interviewees 4 and 7). Thus, it has gradually begun to recognise the strategic significance of developing applicable valorisation options for fines. For instance, according to the recycling facility manager, "the future needs to focus more on smaller sizes" (Interviewee 2). Nevertheless, owing to the level of influence of the prevailing policy, market, and organisational factors, the company will continue with the current disposal-oriented utilisation until it no longer remains an option. As also expressed by one of the process managers, "I would rather continue to do what we are doing right now. Once that opportunity is no longer available, we need to process the material more and find new outlets" (Interviewee 1).

Therefore, to initiate investments in knowledge and technology development for fines valorisation by shredding companies, measures that change the circumstances and settings that sustain the current disposal-oriented practice are needed. The overall findings of this study show that the company's management of fines is primarily influenced by the perceived strategic significance of doing so-something which is primarily influenced by factors occurring on the policy and market levels. Thus, changed external conditions need to be made on these levels, both in terms of challenging the current practice of fines management by removing incentives for utilising the residue in landfill covering and by creating more favourable and foreseeable conditions for SRM utilisation.

\subsection{Challenging the Current Disposal-Oriented Practice}

The principle problem today with the potential fines valorisation is that the current practice of utilisation in landfill covering is a well-established, legislatively compliant, and low-cost disposal option, which offers a secure outlet for the material. As long as these conditions are sustained, it is unlikely that shredding companies would voluntarily seek alternative outlets for fines. Therefore, in order to initiate fines valorisation, measures that challenge the current practice are necessary. One such measure to do so could be the declassification of landfill covering as backfilling. This measure, which is generally deemed necessary to stimulate more value-added recovery and recycling [52], 
would automatically declassify landfill covering as a recovery operation. Consequently, it would necessitate the upgrading and resource recovery of fines in order to comply with the ELV directive targets. It would also take away the current landfill tax exemption of landfill covering, thus removing the financial incentive for this practice. Another plausible measure to remove incentives for utilising fines in landfill covering could be to phase out landfills. This is an ongoing policy in Sweden [14], which needs to be more firmly executed and expedited. Opening up new and acquiring existing landfills has been the practice so far by shredding companies in Sweden (Interviewee 5) and is likely to continue otherwise. Given the ongoing proposals to abolish the disposal of certain waste streams as part of the EU circular economy package [2], more systematic phasing out of landfills in Sweden is foreseeable in the near future. Another, yet more direct way of diverting fines away from landfills, could be to ban or impose excessive taxes on fines disposal, such as the landfill ban on recoverable residues in the Netherlands [53]. That would require shredding companies to opt for fines valorisation in order to both find outlets for the material and comply with the ELV directive targets. However, the successful valorisation of residues (e.g., municipal bottom ash) following the landfill ban in The Netherlands [54] could be explained given the existence of already established SRM markets in the country. In contrast, in Sweden, where such SRM markets still are largely absent, such a ban or high taxation of landfilling might only penalise shredding companies.

\subsection{Creating Favourable Conditions for SRM Utilisation}

The removal of the current incentives for landfill covering is, however, not sufficient to realise fines valorisation. For instance, in the case of declassification of landfill covering as recovery, the shredding companies could pass the increased financial costs of the operation (due to lost tax concessions) onto the waste producers. Continued landfill covering, though, will be subjected to how the ELV directive targets are interpreted and enforced in the country. Alternatively, fines could be mixed with primaries such as sand and gravel to dilute contaminants and utilise in ground construction, which would still qualify as a recovery operation. Therefore, the realisation of fines valorisation also necessitates the addressing of disincentives for developing valorisation options. Creating more established outlets for fines-derived SRMs is one of the two essential means of addressing this issue. Governmental interventions to induce market demand can play a significant role in this regard. Examples could be drawn from Denmark and the Netherlands, where the authorities responsible for national transportation are the primary users of bottom ash-derived SRMs in ground construction applications [28]. Given the comparable socio-economic context, similar measures could be implemented in Sweden as well, for instance, by the Swedish Transport Administration. Policy measures, such as mandating the use of SRMs in public procurement and tenders, are also useful in creating demand. An important prerequisite for governmental interventions to promote SRMs is having the government recognise the need for such materials. Some of the primary reasons behind the pro-SRM policies in Denmark, the Netherlands, and certain other EU countries are the limited land space and accessibility to primary materials [55]. These are not priority issues in Sweden yet, and hence, brisk governmental responses are somewhat too early to expect.

Other than having established outlets for the materials, potential economic gains in producing fines-derived SRMs would also be of great interest for shredding companies as profit-seeking entities. For instance, the studied company makes investment decisions almost entirely based on economic criteria, where all the variables of a given decision situation are assigned a financial value. A similar example is found where a UK-based shredding company has shown an explicit preference to invest in thermal processing of shredder residues rather than meeting the ELV directive targets, given the better economic prospects of the former [56]. When it comes to the economic performance of potential fines valorisation, it is unlikely to pay off by itself, given the low occurrence of valuable resources and the need for extensive processing to address various material constraints [10], and the lack of SRM-market demand. Therefore, policy measures, such as excessive taxing of fines disposal, are deemed necessary to make valorisation investments justifiable, as the avoided costs of disposal would then become 
substantial. Given the early phase of the use of SRMs in general in Sweden, governmental intervention is also deemed necessary to strengthen the competitiveness of fines-derived SRMs in the marketplace. For instance, market instruments such as tradeable credits based on amounts recycled and pre-charged disposal taxes that shall be refunded upon the recycling of residues $[27,57]$ could increase the value of such materials. The taxation of primary resources could also be used to make such materials more attractive to potential users. Investment support schemes for fines valorisation would also be instrumental.

The other essential means of addressing the disincentives for fines valorisation is creating clear market and regulatory playing rules. Regarding markets, a predictable demand and set pricing mechanisms for fines-derived SRMs are crucial, as they make investment decisions for shredding companies more straightforward. Clear user requirements on material quality are also necessary, as they enable shredding companies to develop tailored upgrading and resource recovery processes. Accommodating provisions for fines valorisation in legislation could improve market acceptance and the availability of clear user requirements for fines-derived SRMs. Nevertheless, it is deemed far-fetched, given the early phase of SRM utilisation in the country. For instance, end-of-waste criteria, which could transfer the regulation of the use of SRMs from waste legislation to product legislation, do not exist currently in Sweden for any heterogeneous residue [36]. Additionally, assimilating fines-derived SRMs into REACH (Registration, Evaluation, Authorisation and Restriction of Chemicals) regulations [58], which governs the use of materials in production and manufacturing, would require meticulous investigation of the potential health risks associated with the material. When it comes to the regulation of SRM-based applications, having clear regulatory standards on the allowable contamination levels in SRMs is the key. For instance, material-, application-, and site-specific standards that are nation-wide applicable and binding have been developed in countries such as the Netherlands, Denmark, and Belgium [28,59]. Such standards are further complemented with safety-related specifications, such as maximum layer thickness and minimum elevation from water sources [59,60]. Implementing similar standards in Sweden could, in addition to enabling the development of upgrading and resource recovery processes, avoid the existing inconsistencies between regulatory practices of local authorities, thus making shredding companies as potential investors more confident in the possibilities of implementing different valorisation applications. The development of such clear and foreseeable regulations relies on governmental recognition of the significance of fostering and increasing the utilisation of SRMs.

\section{Conclusions}

The current practice of utilising fines in landfill covering offers the shredding companies in Sweden a secure outlet for the residue. In addition to being an established practice that caters to a significant demand (the LCM market), it provides a legislatively-compliant, low-cost disposal option. On the other hand, the lack of consistently-applied regulatory standards, unfavourable regulation of SRM utilisation applications, and the poor marketability of SRMs create strategic disincentives for shredding companies to opt for valorising fines.

In order to initiate fines valorisation, there is an overall need for incentives in terms of both challenging the current disposal-oriented practice of managing fines and providing more favourable and foreseeable conditions for SRM utilisation. These incentive structures would most likely need to constitute a combination of the policy and market-level measures discussed above. For instance, regarding challenging fines disposal, phasing out landfills alone might not suffice because other disposal-oriented applications might still be accounted for as recovery operations in the legislation. The simultaneous declassification of backfilling as recovery could be used to address this issue. Similarly, regarding creating more favourable and foreseeable conditions for SRM utilisation, the development of established outlets would need complementation by policy instruments targeting improved competitiveness of fines-derived and other SRMs in the marketplace. 
Governmental interventions are key to implementing the aforementioned measures. Currently, applications for SRM reutilisation are found almost only in relation to ground construction. Future possibilities might also exist in the areas of structural construction and production and manufacturing sectors, given that fines contain specific valuable resources such as minerals and metals. In contrast to bulk utilisation, stimulating such applications that involve the development of tailored processes for upgrading and resource recovery would likely require different policy interventions. As much as the interventions via administration, government could also take part in the practice in order to see through to the successful implementation of valorisation applications. An example would be the Green Deals program in the Netherlands, where the government enters into partnerships with industrial actors and encourages and facilitates voluntary solutions to solve a waste situation [61]. Policy-driven initiatives specifically targeting fines are unlikely, however. The focus is usually on either high-value residues, such as electronic and electric residues [62], or large-volume residues, such as municipal bottom ash and slag. Fines valorisation would presumably need to be facilitated within the general framework of policies targeting such residues. Nonetheless, in Sweden, it requires national-level recognition of SRMs as a new demand paradigm in which governmental interventions are a necessity.

One of the future topics of our research is to conduct a demand-side market analysis for secondary raw materials to complement the supplier (shredding company) perspective that has been uncovered in this study. Yet another planned study is to perform a life-cycle environmental impact assessment of alternative applications for fines valorisation in order to provide policy and regulatory guidance.

Supplementary Materials: The following are available online at http://www.mdpi.com/2071-1050/12/22/9540/s1, Supplementary Materials 1: Interview Guides, Supplementary Materials 2: Detailed overview of themes: Table S1. Themes on policy and regulation aspects, Table S2. Themes on market aspects, Table S3. Themes on organisational aspects.

Author Contributions: Conceptualization, T.G. and J.K.; methodology, T.G.; Formal analysis, T.G.; Investigation, T.G.; data curation, T.G.; writing-original draft preparation, T.G.; writing-review and editing, J.K. and H.A.; visualization, T.G.; supervision, J.K. and H.A.; project administration, J.K.; funding acquisition, J.K. All authors have read and agreed to the published version of the manuscript.

Funding: This research was funded by the Swedish Foundation for Strategic Environmental Research (Mistra), grant number DIA 2013/036. The APC was funded by the Linköping University Library.

Conflicts of Interest: The authors declare no conflict of interest.

\section{References}

1. European Commission. Taking Sustainable Use of Resources Forward: A Thematic Strategy on the Prevention and Recycling of Waste; European Commission: Brussels, Belgium, 2005; Available online: https://eur-lex.europa.e u/legal-content/EN/TXT/?uri=celex:52005DC0666 (accessed on 6 November 2020).

2. Bourguignon, D. Closing the Loop-New Circular Economy Package. 2016. Available online: https: //www.europarl.europa.eu/RegData/etudes/BRIE/2016/573899/EPRS_BRI(2016)573899_EN.pdf (accessed on 6 November 2020).

3. Baccini, P.; Brunner, P.H. Metabolism of the Anthroposphere-Analysis, Evaluation and Design; MIT Press: Cambridge, MA, USA, 2012; ISBN 9780262016650.

4. Fischer, T. Getting a return from residue. Scrap 2006, 63, 57-62.

5. Vermeulen, I.; Van Caneghem, J.; Block, C.; Baeyens, J.; Vandecasteele, C. Automotive shredder residue (ASR): Reviewing its production from end-of-life vehicles (ELVs) and its recycling, energy or chemicals' valorisation. J. Hazard. Mater. 2011, 190, 8-27. [CrossRef] [PubMed]

6. Santini, A.; Passarini, F.; Vassura, I.; Serrano, D.; Dufour, J.; Morselli, L. Auto shredder residue recycling: Mechanical separation and pyrolysis. Waste Manag. 2012, 32, 852-858. [CrossRef] [PubMed]

7. Cossu, R.; Lai, T. Automotive shredder residue (ASR) management: An overview. Waste Manag. 2015, 45, 143-151. [CrossRef] [PubMed] 
8. Cossu, R.; Fiore, S.; Lai, T.; Luciano, A.; Mancini, G.; Ruffino, B.; Viotti, P.; Zanetti, M.C. Review of Italian experience on automotive shredder residue characterization and management. Waste Manag. 2014, 34, 1752-1762. [CrossRef]

9. Gunaratne, T.; Krook, J.; Andersson, H.; Eklund, M. Guiding future research on the valorisation of shredder fine residues: A review of four decades of research. Detritus 2020, 9, 150-164. [CrossRef]

10. Gunaratne, T.; Krook, J.; Andersson, H.; Eklund, M. Potential valorisation of shredder fines. Resour. Conserv. Recycl. 2019, 154. [CrossRef]

11. Sveriges Riksdag. Landfill Ordinance (2001:512) on the Landfilling of Waste; Sveriges Riksdag: Stockholm, Sweden, 2001; Available online: https://www.riksdagen.se/sv/dokument-lagar/dokument/svensk-forfattningssamling/f orordning-2001512-om-deponering-av-avfall_sfs-2001-512 (accessed on 6 November 2020). (In Swedish)

12. European Commission. Council Directive 1999/31/EC on the landfill. Off. J. Eur. Communities 1999, 182, 1-19. Available online: https:/eur-lex.europa.eu/legal-content/EN/TXT/?uri=CELEX\%3A31999L0031 (accessed on 6 November 2020).

13. Hansson, D. Mapping of the Final Covering of Landfills. 2013. Available online: https://www.energiforetagen. se/forlag/energiaskor/kartlaggning-av-sluttackning-av-deponier/ (accessed on 6 November 2020). (In Swedish).

14. Swedish EPA. Effects of the Introduction of the Landfill Ordinance. Stockholm. 2010. Available online: https://www.naturvardsverket.se/Documents/publikationer/978-91-620-6381-8.pdf?pid=3688 (accessed on 6 November 2020). (In Swedish).

15. Bareel, P.-F.; Bastin, D.; Bodson, C.; Frenay, J. Sampling of fine Shredder residues (FSR) and characterisation oriented to physical separations. In Proceedings of the Sohn International Symposium Advanced Processing of Metals and Materials, San Diego, CA, USA, 27-31 August 2006; Kongoli, F., Reddy, R.G., Eds.; The Minerals Metals and Materials Society: Pittsburg, PA, USA, 2006; Volume 5, pp. 359-372.

16. Edo, M.; Aracil, I.; Font, R.; Anzano, M.; Fullana, A.; Collina, E. Viability study of automobile shredder residue as fuel. J. Hazard. Mater. 2013, 260, 819-824. [CrossRef]

17. Morselli, L.; Santini, A.; Passarini, F.; Vassura, I. Automotive shredder residue (ASR) characterization for a valuable management. Waste Manag. 2010, 30, 2228-2234. [CrossRef]

18. Sobekova-Foltova, S.; Havlik, T.; Miskufova, A. Recycling of automotive shredder residue by granulometric separation. MM Sci. J. 2017, 1810-1813. [CrossRef]

19. Gent, M.R.; Menéndez, M.; Muñiz, H.; Torno, S. Recycling of a fine, heavy fluff automobile shredder residue by density and differential fragmentation. Waste Manag. 2015, 43, 421-433. [CrossRef]

20. Lewis, G.; Gaydardzhiev, S.; Bastin, D.; Bareel, P.F. Bio hydrometallurgical recovery of metals from fine shredder residues. Miner. Eng. 2011, 24, 1166-1171. [CrossRef]

21. Péra, J.; Ambroise, J.; Chabannet, M. Valorization of automotive shredder residue in building materials. Cem. Concr. Res. 2004, 34, 557-562. [CrossRef]

22. Rossetti, V.A.; Di Palma, L.; Medici, F. Production of aggregate from non-metallic automotive shredder residues. J. Hazard. Mater. 2006, 137, 1089-1095. [CrossRef]

23. Hedenstedt, A. International Analysis of Regulations for Bottom Ash Utilisation; Borås. 2015. Available online: https://docplayer.se/35020215-Omvarldsanalys-avseende-regelverk-for-anvandning-av-bottenas kor-fran-avfallsforbranning-i-fem-lander.html (accessed on 6 November 2020). (In Swedish).

24. Nitivattananon, V.; Borongan, G. Construction and demolition waste management: Current practices in Asia. In Proceedings of the International Conference on Sustainable Solid Waste Management, Chennai, India, 5-7 September 2007; Centre for Environmental Studies, Anna University: Chennai, India, 2007; pp. 97-104.

25. Obernberger, I.; Supancic, K. Possibilities of ash utilisation from biomass combustion plants. In Proceedings of the 17th European Biomass Conference \& Exhibition, Hamburg, Germany, 29 June-3 July 2009.

26. Nayak, N.; Apelian, D. Opportunities and barriers to resource recovery and recycling from Shredder residue in the United States. JOM 2014, 66, 2367-2376. [CrossRef]

27. Dubois, M.; Hoogmartens, R.; Van Passel, S.; Van Acker, K.; Vanderreydt, I. Innovative market-based policy instruments for waste management: A case study on shredder residues in Belgium. Waste Manag. Res. 2015, 33, 886-893. [CrossRef] [PubMed]

28. Johansson, N. How Can Conflicts, Complexities and Uncertainties in a Circular Economy Be Handled? KTH Royal Institute of Technology: Stockholm, Sweden, 2018.

29. Johansson, N.; Krook, J.; Frändegård, P. A new dawn for buried garbage? An investigation of the marketability of previously disposed shredder waste. Waste Manag. 2017, 60, 417-427. [CrossRef] [PubMed] 
30. Van Beers, D.; Bossilkov, A.; Lund, C. Development of large scale reuses of inorganic by-products in Australia: The case study of Kwinana, Western Australia. Resour. Conserv. Recycl. 2009, 53, 365-378. [CrossRef]

31. Miles, M.B.; Huberman, M.A. Qualitative Data Analysis; Holland, R., Ed.; SAGE Publications: London, UK, 1994; ISBN 0-8039-4653-8.

32. Bell, E.; Bryman, A.; Harley, B. Business Research Methods; Oxford University Press: London, UK, 2019.

33. Robèrt, K.H.; Schmidt-Bleek, B.; Aloisi de Larderel, J.; Basile, G.; Jansen, J.L.; Kuehr, R.; Price Thomas, P.; Suzuki, M.; Hawken, P.; Wackernagel, M. Strategic sustainable development-Selection, design and synergies of applied tools. J. Clean. Prod. 2002, 10, 197-214. [CrossRef]

34. Kotter, J.P.; Schlesinger, L.A. Choosing strategies for change. Harv. Bus. Rev. 2013, 2, 34-36.

35. Child, J. Strategic choice in the analysis of action, structure, organisation and environment: Retrospect and prospect. Organ. Stud. 1997, 18, 43-76. [CrossRef]

36. Bertils, E.; Elvingson, H. Development of Markets for Waste-Based Resources-A Case Study on the Reuse of Complex Waste Streams from a Value Chain Perspective; Linköping University: Linköping, Sweden, 2019. (In Swedish)

37. Patton, M.Q. Qualitative Research E Evaluation Methods; SAGE Publications: London, UK, 2002; ISBN 9780761919711.

38. Van Loon, J.; Sabelis, I. Recycling time: The temporal complexity of waste management. Time Soc. 1997, 6, 287-306. [CrossRef]

39. Sveriges Riksdag. Waste Tax Law (1999:673); Sveriges Riksdag: Stockholm, Sweden, 1999; Available online: https://www.riksdagen.se/sv/dokument-lagar/dokument/svensk-forfattningssamling/lag-1999673 -om-skatt-pa-avfall_sfs-1999-673 (accessed on 6 November 2020). (In Swedish)

40. European Commission. Directive 2000/53/EC of the European Parliament and of the Council of 18 September 2000 on end-of-life vehicles. Communities 2000, 6, 34-42. [CrossRef]

41. European Commission Eurostat. Guidance on the Interpretation of the Term Backfilling. 2011. Available online: https://ec.europa.eu/eurostat/documents/342366/4953052/Guidance-on-Backfilling.pdf/c18d330c-97 f2-4f8c-badd-ba446491b47e (accessed on 6 November 2020).

42. European Commission. Directive 2008/98/EC of the European Parliament and of the Council of 19 November 2008 on Waste and Repealing Certain Directives. 2008. Available online: https:/eur-lex.europa.eu/legal-cont ent/EN/TXT/?uri=celex\%3A32008L0098 (accessed on 6 November 2020).

43. European Commission. Laying Down Detailed Rules on the Monitoring of the Reuse/Recovery and Reuse/Recycling Targets Set Out in Directive 2000/53/EC of the European Parliament and of the Council on end-of-life vehicles (2005/293/EC). 2005. Available online: https://eur-lex.europa.eu/legal-content/EN/TXT/? uri=CELEX\%3A32005D0293 (accessed on 6 November 2020).

44. Statens Ofentliga Utredningar. Tax Exemption for Materials Used to Operate the Plant, Construction Work, etc. SOU 2005:64. 2005. Available online: https://www.regeringen.se/49bb3c/contentassets/b 846a3463503465eac3eaefe58a1cc9b/en-braskatt---beskattning-av-avfall-som-deponeras-kapitel-7-10\#: $\sim\{\}:$ text=Enligt $\% 2010 \% 20 \%$ C2\%A7\%203\%20LSA,medges\%20dock\%20inte\%20n\%C3\%A5got\%20avdrag (accessed on 6 November 2020). (In Swedish).

45. Swedish EPA. Recycling of Waste in Construction Sector. 2010. Available online: http://www.naturvardsverk et.se/978-91-620-0164-3 (accessed on 6 November 2020). (In Swedish).

46. Swedish EPA. Guiding Values for Contaminated Soil. 2009. Available online: http://www.naturvardsverket.s e/978-91-620-5976-7 (accessed on 6 November 2020). (In Swedish).

47. Singh, J.; Lee, B.K. Pollution control and metal resource recovery for low grade automobile shredder residue: A mechanism, bioavailability and risk assessment. Waste Manag. 2015, 38, 271-283. [CrossRef]

48. Blasenbauer, D.; Huber, F.; Lederer, J.; Quina, M.J.; Blanc-Biscarat, D.; Bogush, A.; Bontempi, E.; Blondeau, J.; Chimenos, J.M.; Dahlbo, H.; et al. Legal situation and current practice of waste incineration bottom ash utilisation in Europe. Waste Manag. 2020, 102, 868-883. [CrossRef]

49. Avfall Sverige. Swedish Waste Management. 2017. Available online: https://www.avfallsverige.se/fileadmin /user_upload/Publikationer/svensk_avfallshantering_2017.pdf (accessed on 6 November 2020). (In Swedish).

50. Ahmed, N.; Wenzel, H.; Hansen, J.B. Characterization of Shredder residues generated and deposited in Denmark. Waste Manag. 2014, 34, 1279-1288. [CrossRef]

51. Lozano, R. Orchestrating Organisational Change for Corporate Sustainability. Ph.D. Thesis, Cardiff University Business School \& The ESRC Centre for Business, Responsibility, Accountability, Sustainability and Society (B.R.A.S.S.), Cardiff, UK, 2009. 
52. Arm, M.; Wik, O.; Engelsen, C.J.; Erlandsson, M. How does the European recovery target for construction \& demolition waste affect resource management? Waste Biomass Valor 2017, 1491-1504. [CrossRef]

53. Lieten, S.H. Landfill Management in The Netherlands. 2018. Available online: https://rwsenvironment .eu/publish/pages/126540/landfill_management_in_the_netherlands_cocoon_20180503.pdf (accessed on 6 November 2020).

54. Kahle, K.; Kamuk, B.; Kallesøe, J.; Fleck, E.; Lamers, F.; Jacobsson, L.; Sahlén, J. Bottom Ash from WTE Plants: Metal Recovery and Utilisation.; Ramböll: Copenhagen, Denmark, 2015.

55. Dijkgraaf, E.; Gradus, R. An EU Recycling target: What does the Dutch evidence tell us? Environ. Resour. Econ. 2017, 68, 501-526. [CrossRef]

56. Khodier, A.; Williams, K.; Dallison, N. Challenges around automotive shredder residue production and disposal. Waste Manag. 2018, 73, 566-573. [CrossRef]

57. Tekie, H. Mapping of Governing Mechanisms and Guidelines for Construction and Demolition Wastes; IVL The Swedish Environmental Institute: Stockholm, Sweden, 2017. (In Swedish)

58. European Commission. Regulation (EC) No 1907/2006 of the European Parliament and of the Council. 2006. Available online: https:/eur-lex.europa.eu/legal-content/EN/ALL/?uri=celex\%3A32006R1907 (accessed on 6 November 2020).

59. Dou, X.; Ren, F.; Nguyen, M.Q.; Ahamed, A.; Yin, K.; Chan, W.P.; Chang, V.W.C. Review of MSWI bottom ash utilization from perspectives of collective characterization, treatment and existing application. Renew. Sustain. Energy Rev. 2017, 79, 24-38. [CrossRef]

60. Van Gerven, T.; Geysen, D.; Stoffels, L.; Jaspers, M.; Wauters, G.; Vandecasteele, C. Management of incinerator residues in Flanders (Belgium) and in neighbouring countries. A comparison. Waste Manag. 2005, 25, 75-87. [CrossRef] [PubMed]

61. Ellen Macarthur Foundation. Netherlands: Green Deal. Available online: https://www.ellenmacarthurfoun dation.org/case-studies/green-deal (accessed on 11 February 2020).

62. Shahbazi, S.; Jönsson, C.; Wiktorsson, M.; Kurdve, M.; Bjelkemyr, M. Material efficiency measurements in manufacturing: Swedish case studies. J. Clean. Prod. 2018, 181, 17-32. [CrossRef]

Publisher's Note: MDPI stays neutral with regard to jurisdictional claims in published maps and institutional affiliations.

(C) 2020 by the authors. Licensee MDPI, Basel, Switzerland. This article is an open access article distributed under the terms and conditions of the Creative Commons Attribution (CC BY) license (http://creativecommons.org/licenses/by/4.0/). 